\title{
Kierownictwo partyjne wobec wyborów z 4 czerwca 1989 r. w świetle akt Komitetu Wojewódzkiego Polskiej Zjednoczonej Partii Robotniczej w Lublinie
}

ABstrakt: W 1989 r. komuniści dopuścili do częściowo wolnych wyborów w Polsce. Postanowiono zminimalizować liczbę kandydatów na posłów ze strony rządowej, a jak najwięcej osób zgłosić tam, gdzie miejsca nie były zarezerwowane dla przedstawicieli partii pozostających dotychczas u władzy. Chodziło o to, żeby nie rozpraszać głosów na stronę rządową, jednocześnie zdezintegrować wybory stronie opozycyjnej. Wybory w gronie PZPR też miały przebiegać według nowych zasad. Miano wyłaniać kandydatów na parlamentarzystów wśród osób, które rzeczywiście działają na rzecz współobywateli i dobrze prezentujących się w mediach. Co do kandydatów solidarnościowych, to stworzono listę tzw. trudnych pytań oraz innych działań, które miały im utrudnić kampanię. Mimo to wynik wyborów był dla strony partyjnej szokiem. Obwiniano ZSL i SD, że dopuściły do kandydowania z ich list osób z opozycji, a także uczestników okrągłego stołu za niedotrzymanie umowy.

SŁOWA KLUCzowe: NSZZ „Solidarność”, PZPR, wybory 1989 r., okrągły stół.

Podjęte w lutym 1989 r. rozmowy władz PRL z opozycją zaowocowały zmianami w Polsce. Postanowiono m.in. dopuścić do częściowo wolnych wyborów do parlamentu. W Sejmie 35\% mandatów miało być przyznane kandydatom 
bezpartyjnym, pozostałe były zarezerwowane dla przedstawicieli koalicji: Polskiej Zjednoczonej Partii Robotniczej, Zjednoczonego Stronnictwa Ludowego, Stronnictwa Demokratycznego, PAX, Unii Chrześcijańsko-Społecznej i Polskiego Związku Katolicko-Społecznego. Powrócono też do idei Senatu, do którego wybory miały być całkowicie wolne. Tak skonstruowane porozumienie było wstrząsem dla niektórych działaczy PZPR ${ }^{1}$. Po okrągłym stole odbył się cykl szkoleń w partii, które miały na celu przekonanie poszczególnych członków do stanowiska najwyższych władz PZPR.

Inaczej niż w przypadku poprzednich wyborów postulowano, aby te wprowadziły do parlamentu ludzi zaangażowanych w życie społeczne, obdarzonych charyzmą, dobrze prezentujących się w środkach masowego przekazu, a zwłaszcza w TV. Elity partyjne zdawały sobie sprawę ze złej sytuacji gospodarczej, braku mieszkań, trudnej sytuacji w służbie zdrowia, złego funkcjonowania handlu. Dlatego też, przynajmniej w teorii, szukano kandydatów na posłów i senatorów z dużym autorytetem wśród wyborców. Stąd decyzja, aby kandydatem na senatora był pierwszy polski kosmonauta Mirosław Hermaszewski. Podpierano się również autorytetami naukowymi. Z UMCS startowało trzech profesorów: Grzegorz Leopold Seidler na senatora, Józef Szymański i Zbigniew Cackowski na posłów.

Przygotowany już w lutym 1989 r. zestaw zadań na czas kampanii wyborczej zakładał powstrzymanie się od podejmowania niepopularnych decyzji, zwłaszcza co do podwyżek cen. Przeciwnie, na spotkaniu aparatu partyjnego władzom województwa postawiono zadanie uzupełnienia braków na rynku, naprawienia sytuacji w budownictwie i usprawnienia gospodarki poprzez wprowadzanie racjonalizatorskich rozwiązań. Każdy kandydat na parlamentarzystę z nadania partyjnego miał się chlubić dokonaniami, wynikającymi z prowadzonych przez siebie działań. Władze Komitetu Wojewódzkiego zdecydowały także, że powinno się stworzyć sztab wyborczy, który miał powołać instancje partyjne, promujące poszczególne osoby ubiegające się o mandat. Położono duży nacisk na partyjną mobilizację uczestników. Wyrażało się to m.in. nakazem, w myśl którego na każdym spotkaniu wyborczym powinni być obecni ludzie, którzy mieli stwarzać sprzyjającą atmosferę wokół kandydata, zadając mu odpowiednie pytania ${ }^{2}$. Spekulowano również na temat problemów, jakie miała poruszać

1 Archiwum Państwowe w Lublinie (dalej: APL), Komitet Wojewódzki Polskiej Zjednoczonej Partii Robotniczej (dalej: KW PZPR) w Lublinie, 1975-1990, sygn. 1541, s. 189.

2 Ibidem, sygn. 3605, b.p. 
w kampanii wyborczej opozycja. Zaliczały się do nich m.in. ocena 45-lecia rządów partii, rozrachunek z przeszłością (zwłaszcza z okresem stalinizmu), podkreślanie trudnej sytuacji materialnej, niepełny sukces okrągłego stołu. Postulowano aktywną kampanię wyborczą, obejmującą spotkania z wyborcami w ośrodkach kultury, utworzenie przy Wojewódzkiej Radzie Narodowej „Klubu Młodego Wyborcy”. Podkreślano, że odmienność tej kampanii powinna być zasygnalizowana przy pomocy elementów wizualnych, transparentów, plakatów, ulotek. Te ostatnie powinny zawierać zdjęcie kandydata, jego charakterystykę w formie wywiadu, artykułu, rozmowy ze współpracownikami. Nowością miał być także sposób finansowania kampanii. Na posiedzeniu Sekretariatu KW rozważano utworzenie funduszu wyborczego, który miały zasilać odpisy ze składek oraz środki wypracowane w ramach czynów produkcyjnych i społecznych. Proponowano również dwuprocentowy odpis od poborów pracowników $\mathrm{KW}^{3}$.

W kierownictwie partyjnym nie zapominano też o roli Kościoła. I sekretarz KW Andrzej Szpringer poinformował o swoim spotkaniu z arcybiskupem Bolesławem Pylakiem w sprawie zbliżających się wyborów. Spodziewano się neutralnego stanowiska kleru w kampanii ${ }^{4}$. Obawiano się pomocy Kościoła dla opozycji, zwłaszcza wykorzystania jego pozycji społecznej i bazy materialnej.

Na posiedzeniu władz omawiano każdy, nawet najmniejszy aspekt akcji wyborczej. W dniu 31 III poruszono problemy lokalowe. W kontekście kampanii stwierdzono, że "Solidarność” domaga się przyznania lokalu, ale nie można dopuścić, aby ulokowała się w rejonie Krakowskiego Przedmieścia. Sygnalizowano niewielkie zainteresowanie wyborami. Stanisław Jędrych, I sekretarz KM w Puławach, stwierdził, że „trudności dnia codziennego eliminują emocje związane z wyborami”' . Te trudności dotykały nawet działaczy PZPR. Postanowiono, że w okresie niedoborów benzyny należy zabezpieczyć pewne jej ilości, niezbędne w organizowaniu wyborów, dla pracowników KW.

Ponieważ nowa ordynacja wyborcza przewidywała, że o mandat poselski może się ubiegać osoba, która zebrała 3 tysiące podpisów, a o senatorski - 5 tysięcy, obawiano się rozproszenia głosów. Zapowiadano, że w Lublinie będzie od 8 do 10 kandydatów z PZPR, niemniej kierownictwo partii powinno być zainteresowane sytuacją, w której na mandat partyjny przypadałoby 2-3 kandydatów. Wysunięto ok. 200 nazwisk osób aspirujących do zasiadania w parlamencie.

3 Ostatecznie zebrano 9 milionów złotych (KW PZPR w Lublinie, 1975-1990, sygn. 265, s. 53).

4 Ibidem, s. 19.

5 Ibidem, sygn. 686, s. 60. 
Kandydaci mieli przedstawić swój program na plenum KW 9 maja. Zastanawiano się, czy w przypadku uzyskania niewielkiego poparcia zechcą się podporządkować dyscyplinie partyjnej i dobrowolnie wycofać się z kandydowania. Władza sugerowała konieczność przeprowadzenia rozmów dyscyplinujących. Stwierdzono nawet, że nadmiar kandydatów jest pierwszą karą za zbyt duży wpływ tendencji demokratycznych w szeregach partii. Szpringer podsumowując dyskusję, stwierdził, że w okręgu lubelskim wpływy grup opozycyjnych są znaczne, a drugim takim okręgiem są Puławy. W województwie nie stać PZPR na rozbicie indywidualne, jeśli chodzi o kandydatów partyjnych. Stąd wynikał jednoznaczny wniosek: rozmowy dyscyplinujące będą musiały się odbyć.

W przypadku mandatu bezpartyjnego, o który miała ubiegać się też opozycja, wyrażano opinię, by kandydatów było jak najwięcej, aby stworzyć możliwość odebrania stronie solidarnościowej jak największej liczby głosów. Niepokój I sekretarza KW wywołało wycofanie się z kandydowania wielu pretendentów do mandatu z puli miejsc bezpartyjnych. Motywowali oni swoje decyzje stanem zdrowia, chociaż wiadomo było, że uczynili to naciskani przez opozycję.

$\mathrm{Z}$ informacji o sytuacji społeczno-politycznej w województwie lubelskim „dla członków Egzekutywy” z 2 V wynikało, że kandydatami opozycji są ludzie o zdeklarowanych poglądach antykomunistycznych i mający długoletni staż w walce z władzą (Janusz Rożek, Zygmunt Łupina, Adam Stanowski, Henryk Stępniak). Kandydatami tymi byli inicjatorzy ruchów „S” w określonych rejonach: Ignacy Czeżyk w środowisku wsi, Zygmunt Łupina w środowisku oświaty, Tadeusz Mańka w środowisku robotniczym. Władze stawiały na rozdźwięk między opozycją skupioną wokół „Solidarności” a działalnością profesora z Katolickiego Uniwersytetu Lubelskiego Ryszarda Bendera, który zbierał podpisy na własną rękę. Kierownictwo PZPR nie chciało go oficjalnie wspierać, żeby mu nie zaszkodzić, ale $\mathrm{w}$ gronie partyjnym panowało zadowolenie $\mathrm{z}$ jego sposobu działania, bo prowadziło do rozproszenia głosów na mandat bezpartyjny w Lublinie. Nie mniejsze obawy budziła, przypisywana Komitetowi Obywatelskiemu przy Lechu Wałęsie, sprawa rozpracowywania każdego członka PZPR - kandydata na posła lub senatora, odsłaniająca jego słabe strony i dążąca do kompromitowania kandydatów poprzez dostępne, własne środki propagandowe 6 .

Na posiedzeniu Sekretariatu w dniu $5 \mathrm{~V}$ alarmowano, że Solidarność wyznaczyła kandydatów, a partia jeszcze nie ma swoich. Powtarzało się pytanie: „na kogo będziemy grać”. Oznaczało to, że nie wyznaczono konkretnych osób

6 Ibidem, s. 22. 
spośród wielu wskazanych przez PZPR, na których miała skupić się propaganda wyborcza.

Tydzień później dały się usłyszeć obawy, że studenci będą podatni na agitację „Solidarności”. Jednak, jak mówiono: „jest szansa pozyskania studentów programem, który oderwie ich od nudy i szarzyzny". W następnych dniach zauważono dużą aktywność sztabów wyborczych „Solidarności”, wyrażającą się m.in. w intensyfikacji propagandy wizualnej. Zaznaczano, że przeciwnik zarzuca obozowi rządzącemu brak dostępu opozycji do środków masowego przekazu. A przecież, jak powiedziano ze znaczną pretensją, w Radiu Wolna Europa jest bardzo dużo audycji strony solidarnościowej z okręgu wyborczego Lublin, w których dyskredytowani są kandydaci strony rządowej. Stanowczo stwierdzono, że trzeba rozpocząć aktywną walkę propagandową na plakaty w Lublinie. Do rozlepiania tychże postulowano włączyć emerytów, młodzież, np. junaków z Ochotniczych Hufców Pracy. Plakaty można było rozklejać w szkołach, środkach komunikacji publicznej i w witrynach sklepowych. I sekretarz KM Lublin Gustaw Rębacz zaznaczył, że nie będzie problemów z miejscem, ale brak jest obecnie gotowych plakatów. Płk Aleksander Chochorowski zaproponował pomoc poligrafii Wojewódzkiego Urzędu Spraw Wewnętrznych, którego był pracownikiem. Z tego obrazu wyłania się z jednej strony chaotyczność w prowadzeniu kampanii przez kierownictwo PZPR, a $\mathrm{z}$ drugiej niemałe zaskoczenie rozmachem akcji wyborczej ze strony opozycji.

Na posiedzeniu Egzekutywy w dniu $8 \mathrm{~V}$ jeszcze raz stwierdzono, że najlepiej byłoby, gdyby na mandat partyjny kandydowały dwie osoby, a na bezpartyjny jak największa ilość, tymczasem było odwrotnie. Nadal istniał problem dużej liczby kandydatów - członków PZPR, nie tylko wyłonionych przez partię, ale też inne organizacje społeczne. Obawiano się, że wobec takiego obrotu sprawy partia będzie musiała pójść do II tury wyborów. Na $9 \mathrm{~V}$ wyznaczono konferencję plenarną KW, która miała przekształcić się w Wojewódzką Konwencję Wyborczą. Przyjęto, że na plenum wystąpią poszczególni kandydaci, w porządku alfabetycznym. Jednocześnie członkowie Egzekutywy KW powinni się włączać w polemikę w toku dyskusji i w kuluarach, prezentując stanowisko po linii partii, tj. pozostawienie dwóch kandydatów na jeden mandat. W odniesieniu do II tury wyborów Grzegorz Kurczuk, ówczesny kierownik kancelarii I sekretarza, postawił tezę, że nie należy jej się obawiać. II tura głosowania będzie we wszystkich okręgach, nie tylko w Lublinie, ale groźby, iż wyborcy będą brali w niej udział tylko po to, aby wybrać posła PZPR nie ma, choćby dlatego, że mało prawdopodobny jest wybór senatorów w I turze. Hasłem konwencji było „Zgoda buduje”. W tamtym czasie, jak to określano, „centrala”, czyli 
naczelne władze partii, stały jeszcze na stanowisku, że działania propagandowe miały nie mieć charakteru konfrontacyjnego z obozem solidarnościowym? ${ }^{7}$.

Charakterystyczny jest język władz KW. Na posiedzeniu Egzekutywy w dniu 18 V Szpringer wyraził się np. tak: „w grze propagandowej do Sejmu i Senatu jest około 27 kandydatów koalicyjnych i bezpartyjnych, na których gramy jako partia”" Określenie "gra” powtarza się na każdym spotkaniu elity partyjnej. $\mathrm{Na}$ tym posiedzeniu zreferowano też dotychczasowy przebieg kampanii wyborczej. Stwierdzono, że obronną ręką ze spotkań wychodzi tow. prof. Grzegorz Leopold Seidler. Zauważono, że kandydaci „S” nie lubią trudnych pytań - często się gubią przy udzielaniu odpowiedzi. Zaproszony na posiedzenie Tadeusz Fita, redaktor naczelny „Sztandaru Ludu”, zaproponował, aby organizować grupy pikietujących na zebraniach z wyborcami.

Zaobserwowano, że „wredną", jak to określono, kampanię przeciw partii prowadzi Konfederacja Polski Niepodległej. Zapowiadała ona rychłą zmianę ustroju. Odnośnie KPN obawiano się niebezpieczeństwa pikietowania w obrębie lokali wyborczych z udziałem nieletnich członków bojówek tego ruchu, tym bardziej że KPN od początku kampanii prowadziła intensywne działania antykomunistyczne. Podejrzewano, że KPN jest bojówką „,”, wspieraną finansowo i organizacyjnie przez Region Środkowo-Wschodni „S”.

Inny członek narady, pracownik organów bezpieczeństwa, uważał, że „Solidarność" może posunąć się do szantażu wobec członków komisji wyborczych, tak aby w momencie liczenia głosów urna znalazła się w ich rękach, co może doprowadzić do sfałszowania wyborów.

W dniu 26 V Wiesław Sikora, kierownik Wydziału Polityczno-Organizacyjnego, zdał sprawozdanie z narady pracowników aparatu partyjnego. Postanowiono na niej o zorganizowaniu aktywu, który w dniu wyborów, będąc wokół lokalu wyborczego, miał wskazywać, na kogo głosować. Zalecono, aby do $30 \mathrm{~V}$ odbyć spotkania z członkami partii i kierownikami zakładów pracy oraz organizacji społecznych, żeby zobowiązać ich do przeprowadzenia agitacji wśród podległych sobie placówek, a także w gronie rodzin i znajomych. Pracownicy KW mieli też dopilnować, aby w przeddzień wyborów wywieszono propagandę wizualną. Na podstawie wyników badań społecznych oceniono szanse na wygraną w wyborach poszczególnych kandydatów. Zdecydowano, że należy przeprowadzić rozmowy z tymi kandydatami, którzy mają małe szanse i przekonać

\footnotetext{
Ibidem.

8 Ibidem, s. 36.
} 
ich do ustąpienia $\mathrm{z}$ uczestnictwa w wyborach. Komentowano strategię sił opozycyjnych, m.in. na przykładzie Janusza Rożka, który, jak mówiono, prezentuje się w okolicznych wsiach jako bohater. Proponowano, aby przedstawić jego niegospodarność jako rolnika (miano sfotografować w tym celu należące do niego zabudowania gospodarskie).

Na posiedzeniu Egzekutywy w dniu 31 V, sekretarz KW Wiesław Brodowski wyraził zaniepokojenie, że na zebraniach przedwyborczych niektórzy członkowie partii przejawiają wrogi stosunek do partii (jako przykład podał płk. Kosińskiego) ${ }^{9}$. Już wówczas władze KW zaczęły dopuszczać do siebie myśl o ewentualnej porażce $\mathrm{w}$ wyborach. Zdawano sobie sprawę $\mathrm{z}$ niewystarczającej akcji propagandowej. Artur Korobowicz, również sekretarz KW, wyraził pogląd, że partia przegrała wojnę plakatową $\mathrm{z}$ dwóch powodów. Po pierwsze w wyniku błędnego założenia centrali, co do respektowania umowy zawartej przy okrągłym stole i nieatakowania się nawzajem. Drugi powód to fakt, że partia potrafiła działać tylko administracyjne, nie przystosowała się do zmienionej sytuacji, była nieskuteczna. Poza tym wyrażono pogląd, że kandydaci opozycji przypuścili generalny atak na partię, jej dokonania i program.

W okręgu wyborczym Lublin partia nie mogła liczyć też na partnerów koalicyjnych. Szpringer przyznał, że do tej pory nie podjęto działań zmierzających do osiągnięcia porozumienia ze Zjednoczonym Stronnictwem Ludowym i Stronnictwem Demokratycznym. Obawiano się, że największe szanse na listach koalicjantów mają kandydaci o podwójnej przynależności: Teresa Liszcz (ZSL i „Solidarność”) oraz W. Juszczyński (SD i „Solidarność”). A przecież jeszcze w marcu twierdzono, że „ścisłe współdziałanie PZPR, ZSL i SD powinno przede wszystkim dotyczyć taktyki wobec zachowania opozycji, np. by pozbawić opozycję możliwości zbliżenia z ZSL lub SD kosztem osłabienia ich więzi z PZPR”. Poza tym spotkania przedwyborcze ZSL zostały określone jako słabe i zdominowane propozycją założenia nowej partii chłopskiej.

Mimo wszystko, przed I turą wyborów, w części kierownictwa KW panowały optymistyczne nastroje. Uważano, że wystąpienia kandydatów strony rządowej są dobrze przyjmowane. Nawet, gdy spotkania były zakłócane przez

9 Pułkownik Czesław Kosiński, dyrektor Wojskowych Zakładów Inżynieryjnych w Dęblinie, w swoim programie wyborczym ogłosił m.in. następujące postulaty: przyszły Sejm powinien dążyć do całkowitego odpolitycznienia sił zbrojnych; siły zbrojne nie mogą służyć obronie PZPR a ochronie Polski; należy radykalnie ograniczyć wydatki na zbrojenia i ograniczyć wydatki na siły pancerne (KW PZPR w Lublinie 1975-1990, sygn. 1541, s. 1 19). Próbowano go zdyscyplinować podczas rozmów m.in. z Ministerstwem Obrony Narodowej (ibidem, s. 222). 
sympatyków „Solidarności”, którzy zadawali kłopotliwe pytania. Twierdzono, że kandydaci PZPR potrafili na nie odpowiednio zareagować, co spotykało się z zadowoleniem wyborców. Jednocześnie omawiano wiece przedwyborcze kandydatów opozycji. Wbrew wcześniejszym zaleceniom Komitetu Centralnego o niekonfrontacyjnym charakterze kampanii, a wręcz pójściu do wyborów razem z tzw. konstruktywną opozycją, uskarżano się na wybitnie antykomunistyczny stosunek kandydatów „Solidarności”. Podważali oni dorobek PRL i rolę PZPR, która w ich ocenie doprowadziła kraj do ruiny, a jej członków nazywali sługusami Związku Sowieckiego. Szczególnie charakterystyczny jest przykład wiecu w Jastkowie, podczas którego wnioskowano o przywrócenie patrona - Józefa Piłsudskiego - w nazwie Szkoły Podstawowej. Komentarz do tego wydarzenia był następujący: „Jak daleko poszło już uzurpowanie sobie władzy przez „S” na terenie gminy!”10.

Inna część aktywu KW sądziła, że „Solidarność” prowadzi aktywną kampanię, w porównaniu ze słabą akcją wyborczą strony rządowej. Określano ją wprost

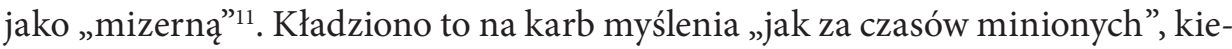
dy nie prowadzono żadnych kampanii wyborczych. Zamiast konsolidacji - po dwóch kandydatów na mandat, wysunięto ich więcej, co doprowadziło do rozbicia głosów. Zlekceważono także opozycję, co według niektórych (jeszcze przed I turą wyborów) stanowiło dla niej dobry prognostyk.

Tuż przed samymi wyborami, 2 VI, zaobserwowano bardziej agresywną propagandę "Solidarności”. Odnotowano, że Region Środkowo-Wschodni otrzymał dużą liczbę afiszy drukowanych we Włoszech. Jak zauważył Artur Korobowicz, dwa ostatnie dni kampanii („wojny plakatowej”) mogą zadecydować o przeciągnięciu niezdecydowanej części wyborców na stronę koalicji. Pracownik aparatu bezpieczeństwa Chochorowski poinformował, że w środowisku wiejskim krążą pogłoski, że skoro partia przegra wybory, to należy głosować na „Solidarność", bo lepiej się jej nie narażać. Chwytano się najdrobniejszych zdarzeń, by uwypuklić dobre strony koalicji i wystawić negatywne świadectwo opozycji. Szpringer powiadomił, że Komitet Obywatelski „S” zaproponował gen. M. Hermaszewskiemu spotkanie z wyborcami na KUL i UMCS, organizowane przez „S”, w zamian za umożliwienie spotkania w Wyższej Oficerskiej Szkole Lotniczej. Takie spotkanie w WOSL się odbyło, natomiast „S” nie wyraziła

10 KW PZPR w Lublinie, 1975-1990, sygn. 265, s. 60.

11 Ibidem, s. 61. 
zgody na udział Hermaszewskiego w spotkaniach na UMCS i KUL. I sekretarz stwierdził, że ten fakt należałoby nagłośnić w prasie.

Mimo to wynik wyborów był dla elity, pozostającej u steru władzy, zaskoczeniem. Po I turze wyborów kierownictwo KW otwarcie stwierdziło, że nie spodziewano się aż takiej klęski. Wybory uznano za „głęboką porażkę. W najczarniejszych prognozach nic nie wskazywało na to, iz „S” zarówno w wyborach do Senatu, jak i do Sejmu uzyska tak przygniatającą przewagę nad kandydatami koalicji”'2. Oskarżano koalicyjne ZSL i SD, które wbiły koalicji „nóż w plecy” pozwalając, by na ich listach zaprezentowali się kandydaci „Solidarności”.

Jednak szybko podjęto przygotowania do II tury. Na zebraniu gremium kierowniczego 9 VI rozważano, czy należy wystąpić z apelem do wyborców o wzięcie udziału w głosowaniu. Ostatecznie zdecydowano nie wystosowywać takiego apelu, za to oddziaływać na społeczeństwo przez artykuły w prasie, dotarcie do Ogólnopolskiego Porozumienia Związków Zawodowych, straży pożarnej, kół gospodyń wiejskich, umiejętnie oddziaływać także na podstawowe organizacje partyjne. Do zadań pracowników KW należała również praca propagandowa w dużych zakładach pracy. Do dyskusji wśród władz doszło w trakcie omawiania kwestii, czy wyznaczać konkretnych kandydatów spośród ubiegających się o mandat poselski i na nich skupić propagandowe wysiłki. Co charakterystyczne, zalecono, aby tow. Sikora zwrócił się, w imieniu Sekretariatu KW, do sojuszników z propozycją wstrzymania się z gratulacjami dla wybranych posłów i senatorów. Z informacji uzyskanych z pionu bezpieczeństwa wydobyto, że „Solidarność” zaleca swoim wyborcom głosowanie na Witolda Chemperka (kandydata PZPR) z uwagi na jego młody wiek i możliwość perspektywicznego oddziaływania na jego osobowość. Poza tym „Solidarność” agitowała znacząco za płk. Czesławem Kosińskim. Na podstawie przeprowadzonej wizyty w Komitecie Zakładowym w Zakładach Elektromaszynowych „Eda” w Poniatowej przedstawiciel partii przybliżył przekazane mu odczucia. Stwierdził, że krytycznie oceniono brak udziału w kampanii wyborczej PRON i administracji zakładu pracy. Zbyt słabe było zaangażowanie kadry kierowniczej administracji państwowej i gospodarczej. „Solidarność” podjęła pracę propagandową już od $3 \mathrm{~V}$ 1989 r. Natomiast partia nie znała swych kandydatów. Panowało przekonanie, że wyborów nie przegrała koalicja tylko partia i rząd, ponieważ wyniki ekonomiczne kraju są bardzo mierne.

\footnotetext{
12 Ibidem, sygn. 1541, s. 105.
} 
Nikt jednak nie spodziewał się aż tak druzgocącej porażki. Podkreślano, że strona rządowa zawiodła się na partnerach z okrągłego stołu, że będą prowadzić niekonfrontacyjną kampanię. Zauważono również ogromną rolę, jaką odegrał Kościól, pomagając „Solidarności” w odniesieniu sukcesu. Po wyborach stwierdzono także, że niektórzy członkowie PZPR wyrażali przekonanie, że władza sprzedała interesy partii.

Elity władzy zdawały sobie sprawę, że po przegranych wyborach PZPR w obecnym kształcie nie ma możliwości aktywnego uczestnictwa w życiu politycznym. Klęska wyborcza komunistów doprowadziła do procesu demokratyzacji rządów w Polsce, a z czasem do rozwiązania PZPR.

\section{Summary}

\section{The Attitude of Party Leadership to the 1989 Elections in Light of the Files of the Provincial Committee of the Polish United Workers' Party in Lublin}

In 1989, the communists agreed to hold partly free elections in Poland. It was decided to minimize the number of the government-backed MP candidates, and to propose possibly many candidates where the seats were not reserved for representatives of the then ruling parties. The idea was to not disperse votes for the government side but at the same time to disintegrate the election for opposition. The elections within the Polish United Workers' Party (PUWP) would also be held according to new rules. Parliamentary candidates would be selected from among those who were actually active for their fellow citizens and looked good in the media. As regards the "Solidarity"-backed candidates, a list of so-called "difficult questions" and other measures was compiled, which were to make their campaign difficult. Nevertheless, the election results were a shock to the PUWP side. The blame was laid on the United Peasants' Party and the Democratic Party for allowing the opposition candidates to run on their tickets, and on the Round Table participants for not keeping the agreement.

KEYWORDS: NSZZ (Independent Self-Governing Trade Union) "Solidarity", PUWP, elections of 1989, Round Table. 


\section{Bibliografia}

\section{Źródła drukowane}

Wybory 1989: dokumenty strony solidarnościowo-opozycyjnej, t. 2, Regiony, red. I. Słodkowska, M. Dołbakowska, E. Krzewska, E. Wosik, Warszawa 2011.

Wybory 1997: partie i ich programy, red. I. Słodkowska, M. Dołbakowska, Warszawa 2004.

\section{Literatura}

Dudek A., Historia polityczna Polski 1989-2015, Warszawa, 2019.

Korulczyk S., Wybory polityczne mieszkańców Radzynia Podlaskiego 1989-2009, Radzyń Podlaski 2015.

Krok ku wolności: wybory czerwcowe 1989 i ich konsekwencje, red. K. Białecki, S. Jankowiak, R. Reczek, Poznań 2015. 